\section{OD INFORMACÍ KE ZNALOSTEM: MEDICÍNSKÉ INFORMACE V DATABÁZÍCH I V ROZHODOVACÍCH SYSTÉMECH}

Alexandra Polášková, Tatjana Dostálová, Lubomír Štěpánek, Pavel Kř́žz, Jitka Feberová, Richard Papík

\section{Anotace}

Informace, resp. vědecké informace $v$ informačních systémech se přesouvají do systémů vyšší kategorie, např. znalostních a rozhodovacích. Velmi dobře znázorňuje tuto záležitost tzv. 4S Haynesova pyramida. Kategorizace a efektivita př́stupu k medicínským informacím. Případová oblast: stomatologie a systémy podpory klinického rozhodování.

\section{Klíčová slova}

vědecké lékařské informace, vědecké informace, databáze, rozhodovací systémy, evidence-based medicine

\section{1 Úvod}

Cílem příspěvku je poukázat na propojovací linku mezi systémy vědeckých lékařských informací a systémy, které slouží k podpoře klinického rozhodování (clinical decision support system). V podstatě Ize konstatovat, že historicky jakékoli formy dokumentů (tištěné i elektronické) vědeckých lékařských informací mají potenciál sloužit v klinickém rozhodování. V (pokračující) době klasických forem i v současných systémech digitálních nebo digitalizovaných informací je symbiotická role medicínského experta a experta na zpracování informací, kterým $\checkmark$ mnoha případech může být i informační pracovník nebo knihovník v roli člena týmu (mj. ve světě zavedených praktik EBM je etablována profese typu „EBM librarian“), pochopitelně zde hrají roli i profese lékařské informatiky se vztahem k počítačové vědě. $\mathrm{V}$ týmu pochopitelně dominantní roli hraje medicínský profesionál znalý problematiky daného klinického oboru. Je možné také poukázat na zajímavou novou profesi či obsah činností, které se dostávají ve světě i pod označení typu "health content advisor". V oblasti databází vědeckých lékařských informací i v systémech podpory klinického rozhodování je možno vidět reálnou nebo potenciální spolupráci několika profesí, i když rozhodujícím tvưrcem a konceptorem vědeckých lékařských informací bude vždy medicínský profesionál, ponejvíce lékař, jak bylo zmíněné a jak musí být opětovně zdůrazněno.

\section{Kategorizace databází}

Databáze používané pro řešení informačních potřeb v lékařských a souvisejících oborech jsou uživatelům, zvláště těm pokročilým a naučeným je využívat, relativně již dobře známy (za všechny leze zmínít - zde opravdu jen výběrově - Medline (resp. také PubMed), dale EMBASE, Biological Abstracts, International Pharmaceutical Abstracts, EBM Reviews, UpToDate a desítky dalších databází na podporu získávání vědeckých lékařských informací i klinického rozhodování. Databáze je možné kategorizovat z více či dokonce mnoha hledisek. Svým způsobem by mohly být použity desítky náhledů na kategorizaci, ale pro potřeby této práce je možno vystačit s následujícími kategoriemi databází.

Klasifikace $z$ hlediska formy dokumentu:

- textové

- multimediální

- hybridní (kombinace předešlých forem)

Klasifikace dle vztahu k získané cílové informaci:

- referenční (odkazové) - odkazují na další zdroje informací, uživatel musí učinit další kroky k získání primární informace

- zdrojové - obsahují cílovou - primární informaci

Klasifikace dle podle typu poskytovaných informací:

- bibliografické

- faktografické

- plnotextové

- typu rejstř́iků, adresářů a seznamů

Klasifikace podle oborového zaměření:

- univerzální

- víceoborové (polytematické)

- oborově zaměřené

Klasifikace podle počtu záznamů:

- velké (stovky tisíc záznamů, dokumentů)

- střední (desítky tisíc záznamů, dokumentů)

- malé (tisíce, stovky dokumentů)

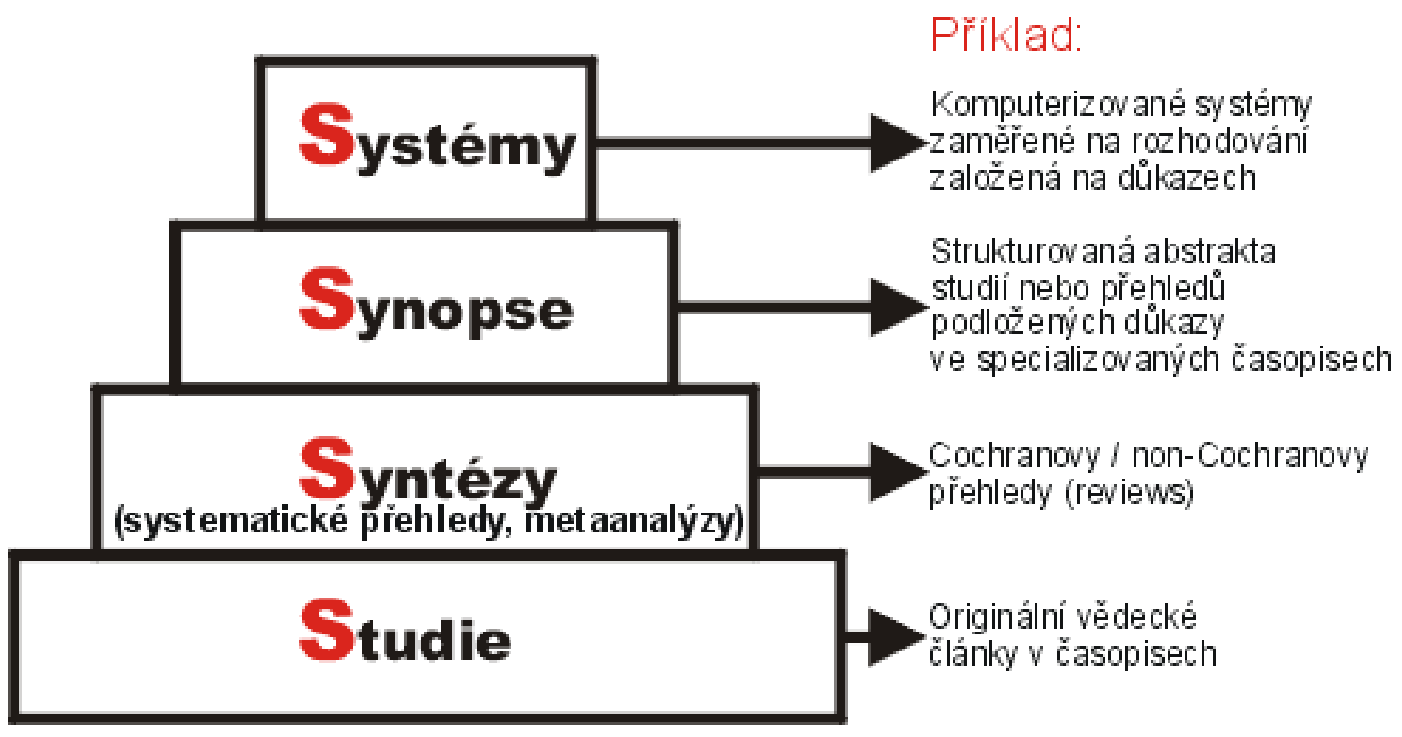

Obrázek 1 - Příklad systémů a typů informací využívaných v oblasti klinického rozhodování [9]. 


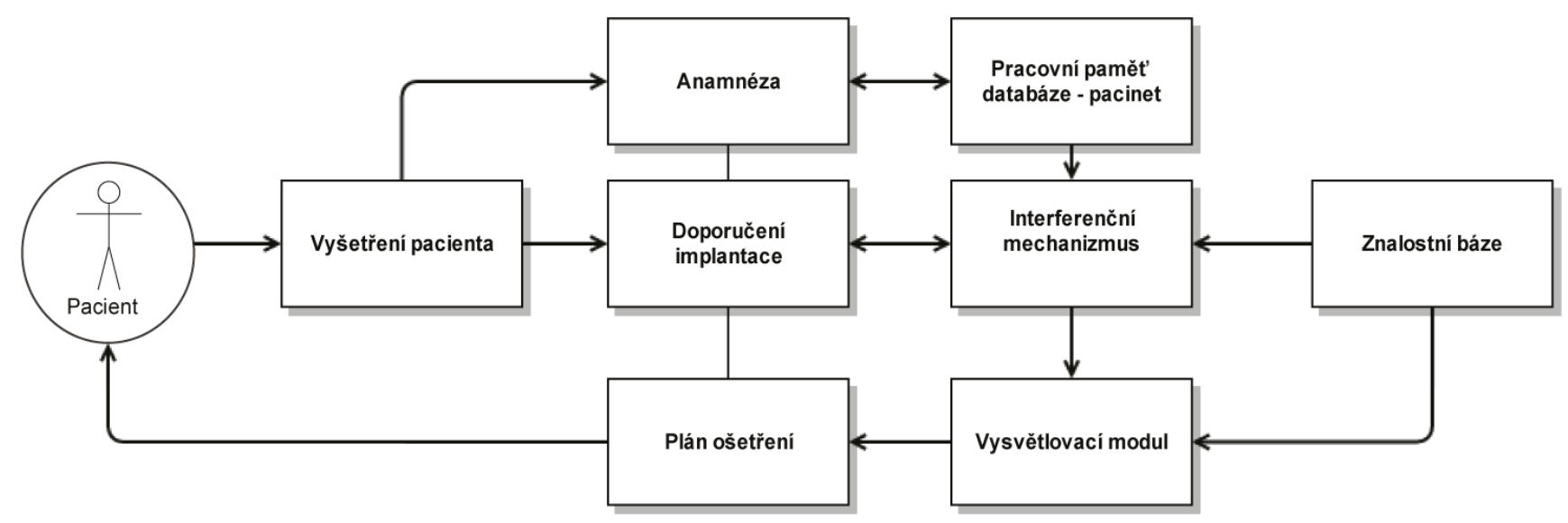

Obrázek 2 - Příklad systémů a typů informací využivaných v oblasti klinického rozhodování [9].

Klasifikace dle přístupnosti:

- volně a zdarma prístupné

- placené

- přístupné na základě registrace či členství

- veřejně nepřístupné (přístupné jen v institucích, např. firmách)

V současnosti se $v$ prostředí vědeckých lékařských informací, ale i dalších typů medicínských informací objevují hybridní varianty předchozích rozdělení databází, např. plnotextové databáze, ale stále častěji databáze faktografické, zároveň např. i formou dokumentů multimediální, také vzniklé jako komerční produkt u profesionálních nakladatelů či vydavatelů nebo $\checkmark$ rámci výzkumných aktivit na odborných pracovištích. Ke slovu se dostávají kromě tzv. EBM (evidence-based medicine) informačních systémů systémy podpory klinického rozhodování (clinical decision support systems).

\section{Klinické systémy na podporu rozhodování}

Klinické systémy na podporu rozhodovaní (Clinical Decision Support System - CDSS) se vyvíjely od 70 let v minulém století. Klasifikace těchto systémů se upřesňuje na základě utilizace nových metod na zpracování dat v těchto systémech. Dnešní CDSS vznikají z předešlých výzkumů předchozích systémů jako byly znalostní systémy, které zahrnují expertní systémy, diagnostické systémy, plánovací expertní systémy. Podle Berner and Lande[1] se CDSS rozděluje na Znalostní systémy - (Knowledge-Based Clicnical Decission Support System) a Systémy s umělou inteligencí (Nonknowledge-Based Clinical Decision Support Systém) - Systémy s umělou inteligencí, které využívají metody strojového učení pro zpracování objemnějších dat. $U$ těchto systémů se nepředpokládá role experta či modulu báze znalostí, tento modul se nahrazuje právě metodologií data mining (dolovaním dat). Obecně Ize definovat klinické systémy na podporu rozhodování jako programy, které mají podporovat lidské odborné rozhodnutí. Jedná se o technologický nástroj zahrnující software a hardware pro elektronické zpracování dat, který poskytuje expertní podporu pro navržení diagnózy, modelu léčby a dál. Mohou to být samostatné programy, webové aplikace či sdílené virtuální technologické prostředí. Tyto systémy $v$ medicíně ve většině prípadech jsou navrženy tak, aby zvyšovaly kvalitu zdravotní péče, eliminovaly rizika rozhodování, šetřily čas a peníze. [2-6]

Expertní systémy jsou podmnožinou znalostních klinických systémů na podporu rozhodování, které jsou charakteristické svou danou strukturou jako je báze znalostí a inferenční mechanismus, komunikačním a vysvětlujícím modulem. Cílem těchto systémů bylo simulovat rozhodování experta v daném oboru, na základě dat vycházejících z báze znalostí a jejich zpracování v rámci inferenčního mechanismu. Expertní systémy se dále dělí na diagnostické a plánovací. Prvními medicínskými expertními diagnostickými systémy byl např. MYCIN (program, který navrhoval léčbu antibiotiky pro různá infekční onemocnění). Tento systém byl vyvinut ve Výzkumném institutu na Stanfordské univerzitě. PUFF - program na interpretaci obstrukcí dýchacích potíží. [7-8] V jiných oborových odvětvích např. v geologii to byl Prospector, v chemii Dendral.

$S$ rozvojem výpočetní techniky a vzhledem k velkém objemu dat vyskytujících se v odborných databázích a jejich získání a zpracování se častěji využívají techniky metodologie data mining (jako jsou rozhodovací stromy, logická regrese, clusterové analýzy, umělé neuronové sítě). V dnešní době jsou vyvíjeny systémy hybridní kombinací metod jako jsou Bayesovské sítě, rozhodovací stromy, umělé neuronové sítě, fuzzy logika a dalšími metodami strojového učení.

\section{Klinický systém na podporu rozhodování pro plán ošetření a aplikace implantátu}

Na stomatologické klinice dětí a dospělých tým vytvořil webovou aplikaci, obsahující systém pro podporu rozhodovaní pro aplikaci implantátu. Aplikace je součástí virtuálního vzdělávacího prostředí a je tedy dostupná akademické obci, ale existuje možnost ji zpřístupnit na požádání odborným expertům či zájemcům. Výstupem systému je doporučená optimální zubní rehabilitace pro lékaře a pacienta. Jedná se o interaktivní aplikaci, která poskytuje klinické doporučení k zavedení implantátu a plán ošetření.

\section{Metody}

Samotná aplikace obsahuje základní složky znalostního klinického systému na podporu rozhodování, jako jsou báze znalostí, inferenční mechanismus, vysvětlující modul a pracovní pamět'.

Samotná aplikace je tvořena 4 moduly; Anamnéza pacienta, interaktivní modul - doporučná implantace (zahrnující výběr chybějících zubů, zadání metrických hodnot anatomických podmínek chrupu), vyšetření pacienta a kartotéku. Jádro systému je tvořeno rozhodovacím stromem, který byl vytvořen na základě logického schématu kvalifikačních kritérií, který zohledňuje anatomické podmínky, jako jsou šírka mezery a kosti. Na základě výběru chybějících zubů a zadání naměřených parametrů šiřky mezery a kvantity kosti získá lékař doporučení pro aplikaci implantátu (viz obr. 3).

Samotná aplikace je naprogramována v programovacím jazyce php, mysql. Pro webový interface pak následně webový programovací jazyk Javascript, značkovací jazky html a kasadový styl. 


\section{Dvojčlenná mezera}

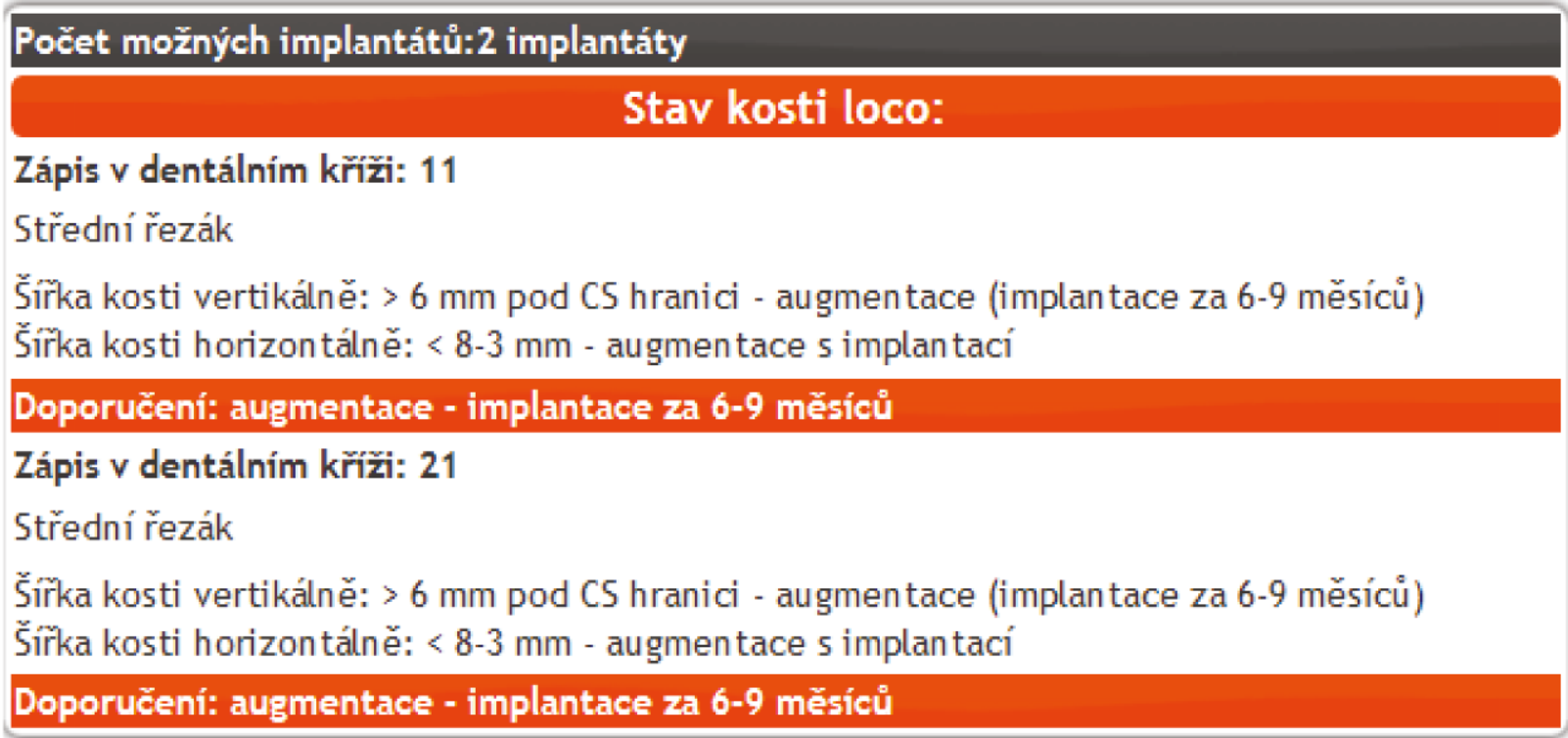

Nové zadání

Obrázek 3 - Doporučení pro aplikaci implantátu

\section{Výsledky}

Pro ověření aplikace v praxi jsme vytvořili pilotní studii, zahrnující 28 pacientů, kteří byli vyšetřeni odbornými lékaři se zaměřením na stomatologii a specialistou na implantologii.

Za základní statistický vzorek byla volba indikace zubní implantační terapie implantologickými specialisty a dalšími zubními lékaři. Pro statistickou analýzu jsme použili datový soubor s 315 indikací terapie zubním implantátem. Indikace obsahuje pět možných metod použitelných pro zubní terapii (implantace, implantace s augmentací, implantace augmentací 4-9, implantace augmentací 6-9, ortodoncie nebo stripování). Konfúzní matice a přesné binomické testy byly použity k otestování, zda existují nějaké statisticky významné rozdíly mezi pozorovanými frekvencemi indikací k implantační terapii a těmi, které se očekávají v prípadě, že implantáty budou indikovány pouze náhodně. Zubní lékaři byli rozděleni do dvou skupin - mladí a zkušení - před analýzou. U dvou zkušených zubních lékařů bylo 126 indikací pro léčbu dentálních implantátů, 189 indikací pro tři mladé zubní lékaře a 315 indikací zcela v rámci léčené skupiny 28 pacientů. Každá z indikací byla zahrnutá do konkrétní konfúzní matice, zkušení zubní lékaři a mladí zubní lékaři. Logistická regrese byla provedena za účelem identifikace nezávislých prediktorů spojených s úspěšnými a neúspěšnými indikacemi. Celková statistická významnost každého nezávislého prediktora byla potvrzena Waldovým $\times 2$ testem.

\section{Závěr}

Klinická pracoviště, dále knihovny a informační instituce, informační (resp. také informatičtí) profesionálové a knihovníci spolu s medicínskými profesionály, ale všichni s významným vztahem $\mathrm{k}$ vědeckým lékařským informacím se podílejí tvorbou dokumentů i informačních nebo znalostních systémů na podpoře klinického rozhodování. Bylo cílem poukázat na jistou provázanost publikovaných dokumentů vědeckých lékařských informací vedoucích $\mathrm{k}$ vyšším formám využitelných v oblasti EBM až po specializované systémy podpory klinického rozhodování, které završují znalostní základnu. Zde byl uveden př́klad takového systému aplikovaný v oblasti stomatologie.

\section{Literatura}

[1.] Berner E. S. La Lande T. J. (2007). Overview of Clinical Decision Support Systems. In BernerE. S. (Ed.), Clinical Decision Support Systems (pp. 3-22). New York: Springer. 10.1007/978-0-387-38319-4_1

[2.] Suebnukarn S, Rungcharoenporn N, Sangsuratham S. A Bayesiandecision supportmodel forassessmentofendodontictreatmentoutcome. Oral SurgOral Med OralPathol Oral RadiolEndod. 2008 Sep;106(3):e48-58.

[3.] Sittig DF, Wright A, Osheroff JA, Middleton B, Teich JM, Ash JS, Campbell E,Bates DW. Grand challenges in clinicaldecision support. J Biomed Inform. 2008Apr;41(2):387-92.

[4.] Wright A, Sittig DF. A framework and model forevaluatingclinicaldecisionsupport architectures. J BiomedInform. 2008 Dec;41(6):982-90.

[5.] Vikram K, Karjodkar FR. Decision support systems in dental decision making: an introduction. J EvidBasedDentPract. 2009 Jun;9(2):73-6.

[6.] Oladele T. O, and Sanni Y. Article: Dental Expert System. International Journal of Applied Information Systems. 2015 Jan; 8(2):1-15.

[7.] Šedivá E., Hart L., Dostálová T., Přehled expertních systémů v medicine a ve stomatologii, Prakt. zub. Lék., roč. 65, 2017, č. 1, s. 3-7.

[8.] ZVÁROVÁ, Jana, SVAČINA, Štěpán a Zdeněk VALENTA, ed. Biomedicínská informatika. Praha: Karolinum, 2009. ISBN 978-80-246-1732-9.

[9.] PAPÍKOVÁ, Vendula. Strategie vyhledávání aktuálních a důkazy podložených informací pro potřeby klinické praxe. Ikaros [online]. 2002, ročník 6, číslo 2 [cit. 2018-03-02]. urn:nbn:cz:ik-10873. ISSN 1212-5075. Dostupné z: http://ikaros.cz/node/10873 


\section{Kontakt}

Mgr. Alexandra Polášková

prof. MUDr. Tatjana Dostálová, DrSc., MBA.

MUDr. Lubomír Štěpánek

MUDr. Pavel Kř́iž

MUDr. Jitka Feberová, Ph.D.

2. lékařská fakulta Univerzity Karlovy a Fakultní

nemocnice Motol

V Úvalu 84, 15006 Praha 6

Doc. PhDr. Richard Papík, Ph.D.

Ústřední knihovna Univerzity Karlovy

José Martího 407/2

16200 Praha 6 - Veleslavín 